DOI: 10.20472/IAC.2019.051.020

NIAN LIU

Sociology Department, Guangzhou University, China

\title{
THE IMPACT OF LEARNING ORIENTATION ON PROFESSIONAL IDENTITY AND OCCUPATIONAL WILLINGNESS OF SOCIAL WORK STUDENTS
}

\begin{abstract}
:
Learning orientation refers to students' attitudes, motivations and learning strategies towards professional learning. A four-year follow-up survey of 158 social work undergraduates indicates that deep learning orientation has a positive and significant impact on students' professional identity and willingness to be a social worker. The more interested social worker students are in professional knowledge, the more satisfied they can obtain knowledge through professional education, and the stronger professional identity of social work is, the more likely they are to engage in becoming social workers when graduate. With the reflection on the current curriculum of judicial social work, problem-oriented approach, experiential education and vocational guidance are suggested to be applied into the course.
\end{abstract}

\section{Keywords:}

Learning orientation, social work, professional identity, follow-up study 